\title{
PAKU ALAM V: SANG ARISTO-MODERNIS DARI TIMUR
}

\author{
Sudibyo \\ Jurusan Sastra Nusantara, FIB, Universitas Gadjah Mada, Yogyakarta \\ sudibyomg79@gmail.com
}

\begin{abstract}
This paper recites Paku Alam $V$ figures as an ambiguity subject and a cultural paradox. He lived in a kingdom economic crisis and a rapid flow of changes in politics, economy, laws, and lifestyle aspects which is caused by other colonial social elements. The analysis focuses on psychological, religious, and cultural aspects which form his personality. To achieve the goal, it uses post colonialism concerning in contact zone, textual studies and historical context. The textual studies are used to explain the role modernization in genealogy, consistence, and Paku Alam V mind revolution. The historical context is used to explain the historical background, especially related to zeitgeist, when Paku Alam V implemented his ideas.
\end{abstract}

Keywords: aristocrat, paradox, text, context.

\begin{abstract}
ABSTRAK
Tulisan ini mengkaji sosok Paku Alam V sebagai subjek ambiguitas dan paradoks kebudayaan. Ia hidup di tengah krisis ekonomi kerajaan dan arus perubahan yang deras di bidang politik, ekonomi, hukum dan gaya hidup yang dihembuskan oleh kekuasaan dan elemen-elemen masyarakat kolonial lainnya. Analisis difokuskan pada aspekaspek psikologis, religious, dan kultural yang membentuk pribadinya. Untuk mencapai tujuan itu, digunakan teori poskolonialisme tentang zona kontak dan kajian teks serta konteks sejarah. Kajian teks digunakan untuk menjelaskan peran modernisasi dalam genealogi, konsistensi, dan evolusi atau revolusi pemikiran P.A. V. Konteks sejarah digunakan untuk menjelaskan latar belakang sejarah, khususnya yang berkaitan dengan zeitgeist saat P.A. V mengimplementasikan gagasan-gagasannya.
\end{abstract}

Kata kunci: aristrokat, modernis, paradoks, teks, konteks

\section{PENDAHULUAN}

B.R.M. Noto Wiloyo, nama kecil dari Paku Alam V (P.A. V), yang setelah dewasa bergelar P.A. Suryo Dilogo adalah putra ke-14 dari enam belas putra K.G.P.A. Paku Alam II. Ia lahir dari salah seorang istri P.A. II yang berasal dari kalangan biasa, bernama Resminingdyah. Setelah melahirkan anak pertama, Noto Wiloyo, dengan alasan yang tidak jelas, Resmingdyah dikeluarkan dari istana dan dikawinkan dengan Rio Bupati Pangreh Praja Brosot, Raden Rio Sosroamijoyo. Tidak lama setelah mengawini Resminingdyah, Sosroamijoyo dipromosikan di istana sebagai bupati patih (Cakrasumarta dan Himadigdaya, 1987: 31).

Ketika Resminingdyah dikeluarkan dari istana, Noto Wiloyo masih remaja. Tanggung jawab pengasuhannya dibebankan pada kepatihan dan pada waktu itu patih masih memiliki hak mendapatkan lahan untuk menopang keberadaannya yang disebut dengan siti narawita. Hasil dari budidaya lahan itu digunakan untuk memelihara anak-anak kerabat istana yang memerlukan pengasuhan. Pada waktu 
Noto Wiloyo berada di lingkungan kepatihan, terdapat kerabat lain yang tinggal di tempat itu. Noto Wiloyo kemudian menjadi anggota legiun Pakualaman.

Pada suatu ketika, R.M. Noto Wiloyo mendapatkan murka dari dari ayahandanya, P.A. II. Noto Wiloyo diusir dari istana Pakualaman dan diasingkan di Desa Bugel, Adikarta di bawah pengawasan pejabat pangreh praja di wilayah itu. Sama dengan ibundanya, alasan pengucilan Noto Wiloyo juga tidak banyak diketahui orang.

Di tempat pengasingan, Noto Wiloyo dengan tekun mempelajari kepangrehpraja-an (hal-hal yang berhubungan dengan tata pemerintahan) di bawah tuntunan Panewu Pangreh Praja Bugel, Ngabehi Reksodiwiryo. Interaksi secara intens antar keduanya membuat hubungan mereka menjadi sangat akrab. Tidak kelihatan bahwa mereka berasal dari keluarga yang berbeda,satu dari istana yang lain dari kalangan rakyat biasa. Ketika Reksodiwiryo berhenti sebagai panewu pangreh praja Bugel karena usia, Noto Wiloyo tampil menggantikan kedudukannya. Dari situlah, dia semakin banyak mendapatkan pengetahuan ke-pangrehprajaan-an. Di samping ke-pangrehpraja-an, Noto Wiloyo juga tertarik menekuni pertanian dan pengairan. Ia mengasah keterampilan dalam bidang itu di bawah bimbingan Ngabehi Rekso Prayitno sampai memiliki kemampuan yang memadai.

Setelah beberapa waktu dalam pengasingan dan merasakan penderitaan dipisahkan dari keluarga besarnya, Noto Wiloyo memiliki keinginan yang kuat untuk mengunjungi keluarga besarnya di Kadipaten Pakualaman. Ia sempat merasa ragu apakah akan ada salah seorang anggota keluarganya yang berani menyambut kehadirannya karena selama dalam pengasingan ia sama sekali tidak menerima tegur sapa dari mereka. Akan tetapi, karena dorongan itu sangat kuat ia memutuskan untuk mengunjungi sanak saudaranya di istana Pakualaman. Sembari menentukan salah seorang saudaranya yang akan dikunjungi, ia bertekad jika kunjungannya itu dianggap sebagai dosa baru ia rela untuk meninggalkan istana Pakualaman untuk selama-lamanya.

Perjalanannya kembali ke istana Pakualaman menuntunnya ke rumah B.R.M. Ario Sasraningrat (kelak P.A. III). Kedatangannya disambut gembira oleh Sasraningrat. Di hadapan Sasraningrat, Noto Wiloyo pun menyatakan tekadnya. Jika kepulangannya tidak dikehendaki, ia akan meninggalkan istana Pakualaman untuk selamanya. Oleh Sasraningrat ia dihibur dan ditenangkan hatinya. Bahkan, kakaknya itu bersedia menanggung akibat menerima kehadirannya kembali di istana Pakualaman. Oleh Sasraningrat ia ditempatkan di Sasraningratan dengan tugas membantu menulis dan menyalin karya sastra karena Sasraningrat sendiri menekuni kesusastraan.

Lama-kelamaan, keberadaan Noto Wiloyo di Sasraningratan didengar oleh K.P.H. Nataningprang. Untuk itu, Sasraningrat dipanggil oleh Nataningprang. Nataningprang menanyakan kebenaran kabar bahwa Noto Wiloyo bertempat tinggal di Sasraningratan. Semuanya diakui oleh Sasraningrat. Pengakuannya menyebabkan kemarahan Nataningprang. Sasaningrat dimarahi oleh Nataningprang karena dianggap melindungi Noto Wiloyo yang sedang mendapatkan hukuman dari penguasa yang sedang bertahta. Sasraningrat beralasan bahwa meskipun tengah menjalani hukuman, bagaimanapun juga Noto Wiloyo adalah putra Paku Alam yang sedang bertahta sehingga layak mendapatkan perlin- 
dungan. Jawaban yang sama juga disampaikan kepada ayahandanya, Paku Alam II ketika Sasraningrat dipanggil menghadap. Tanpa ragu-ragu, Sasraningrat mengemukakan kepada ayahandanya alasan yang sama. Jawaban yang dilandasi kejujuran dan rasa cinta terhadap Noto Wiloyo itu dapat meluluhkan hati Paku Alam II. Noto Wiloyo diampuni kesalahannya dan dikembalikan pada posisinya sebagai anggota Legiun Pakualaman.

Selama masa pengasingannya di Brosot dan Bugel, Noto Wiloyo juga menjalani kehidupan asketisme (Ringkesaning Wewaton, t.t.: 2). Pengasingan Noto Wiloyo mirip dengan yang dialami oleh Pangeran Noto Kusumo ketika diasingkan oleh Sultan HB II dan berakhir dengan penobatannya sebagai Paku Alam I. Ada ramalan bahwa Noto Wiloyo akan mengalami hal yang sama dengan kakeknya karena mereka percaya bahwa Noto Wiloyo telah mendapatkan wahy u raja (Sosrosoedarmo, 1931: 32).

Beberapa peristiwa penting yang membukakan peluang bagi Noto Wiloyo (P.A. Suryo Dilogo) untuk menduduki tahta Kadipaten Pakualaman adalah krisis kaderisasi dan buruknya kondisi kesehatan Paku Alam yang tengah bertahta. Pertama, K.P.H. Nataningprang, putra P.A. II dari permaisuri, Gusti Kanjeng Ratu Ayu yang diharapkan akan menggantikan ayahandanya, meninggal sebelum naik tahta. Kedua, tidak lama sesudah itu, pada 23 Juli 1858 , P.A. II menyusul wafat. Ketiga, B.R.M.A. Sasraningrat yang menggantikan ayahnya sebagai K.G.P.A. Ario Suryosasraningrat (P.A. III) hanya enam tahun duduk di atas tahta karena wafat pada 17 Oktober 1864. Keempat, K.P.A. Nataningrat, putra K.P.A. Nataningprang ditetapkan menggantikan pamannya sebagai P.A. IV karena kedua putra P.A. III dari permaisuri tidak me- menuhi syarat untuk duduk di atas tahta. Putra pertama, Pangeran Suryaningrat menderita gangguan penglihatan (buta), sedangkan adiknya, Pengeran Sasraningrat masih terlalu muda.

Pada saat suksesi sesudah wafat P.A. III, berkat jasa ibunya, Gusti Kanjeng Ratu Ayu yang memiliki hubungan erat dengan residen, penunjukkan Pangeran Adipati Suryo Sasraningrat sebagai P.A. IV berjalan dengan mulus. Selama kepemimpinan P.A.A. Suryo Sasraningrat, beberapa wilayah Kadipaten Pakualaman mengalami kemunduruan dari segi finansial dan ketidaksejahteraan. P.A. IV tidak memiliki kemampuan yang memadai sebagai penguasa puro. Di samping itu, gaya hidup Sang Adipati yang mewah juga merupakan penyebab krisis. Kadipaten Pakualaman dililit utang kepada sejumlah bank Belanda. Dalam keadaan krisis, P.A.A. Suryo Sasraningrat tidak mendapatkan dukungan moral dari anak-anak P.A. III karena Sasraningrat dianggap telah melalaikan mereka. Perang dingin antara P.A. IV dengan para pewaris langsung P.A. III ini turut memperparah keadaan sampai dengan kepulangan P.A. Sasraningrat pada 24 September 1878 (Vereeniging Habi Darmo Wargo, 1931: 22-23).

Sepeninggal Pangeran Adipati Suryo Sasraningrat (P.A. IV), suksesi di Praja Pakualaman kembali tersendat karena almarhum tidak memiliki anak laki-laki. Setelah melalui musyawarah yang suntuk diputuskan Pangeran Ario Suryo Dilogo sebagai penerusnya. Penunjukkan P.A. Suryo Dilogo dimudahkan oleh conditio sine qua non di atas. Penetapan Paku Alam V ini dikukuhkan dengan Gouvernementsbesluit No. 7, tanggal 15 Desember 1878. Gelar beliau adalah Pangeran Adipati Aria (P.A.A.) Prabu Suryo Dilogo. Sebagian orang yang tidak mengetahui kapasitas Suryo Dilogo merasakan keanehan dengan 
Paku Alam V ... - Sudibyo

penobatan ini. Mereka menunjukkan sikap a priori dan menyebarkan desasdesus. Akan tetapi, harian De Locomotief pada edisi 27 September 1878 menunjukkan optimisme dengan penobatan P.A.A. Prabu Suryo Dilogo dan tidak ragu-ragu mengomentari penoba$\tan$ P.A.A. Prabu Suryo Dilogo itu dengan pujian "the Right man in the right place".

\section{BERPIKIR MALAMPAUI ZAMAN}

P.A.A. Suryo Dilogo naik tahta pada saat pemerintah kolonial Belanda memberlakukan liberalisasi di bidang ekonomi. Salah satu implementasinya muncul perkebunan-perkebunan swasta yang besar (Lombard, 1996: 53 dan Furnivall, 2009: 187-188). Para pekebun mengupayakan komoditas ekspor untuk pasar dunia, seperti gula, kopi, tembakau, dan nila. Didorong oleh permintaan yang semakian besar akan komoditas itu, para pemilik perkebunan besar semakin bersemangat menyewa tanah dari para pemilik tanah.

Di wilayah kerajaan terutama di Yogyakarta dan Surakarta penyewaan tanah tidak hanya terbatas pada tanah milik perorangan, tetapi juga merambah ke tanah lungguh. Banyak tanah lungguh di Yogyakarta dan Surakarta yang disewa oleh para pengusaha perkebunan besar. Tak terkecuali para bangsawan Kadipaten Pakualaman. Mereka merelakan tanah lungguh-nya disewa oleh para tuan tanah untuk membiayai kehidupan mereka. Tindakan penyewaan tanah merupakan andalan para bangsawan untuk menopang gaya hidup mereka.

Para pekebun memiliki akses ke istana karena mereka merupakan elite masyarakat kolonial pada waktu. Di Yogyakarta, sebagian dari mereka yang notabene anggota Tarikat Mason Bebas
(Vrijmetselarij) memiliki kedekatan dengan kehidupan istana. Kedekatan itu antara lain dibuktikan dengan kebiasaan tukar-menukar hadiah, kehadiran mereka dalam permainan kartu yang diselenggarakan di istana, dan sebaliknya pihak keraton memfasilitasi Tarikat Mason Bebas dengan sebuah bangunan milik keraton yang kemudian dijadikan sebagai pusat kegiatan Mason Bebas Loji Mataram. Tidak hanya itu, para penghuni istana kemudian tercatat sebagai anggota aktif dan terlibat dalam kegiatan-kegiatan Tarikat Mason Bebas (Bosma and Raben, 2008: 118-119).

Apabila para pemilik perkebunan menyewa tanah lungguh untuk kepentingan peningkatan produksi komoditas ekspor dan pada gilirannya peningkatan kemakmuran, tidak demikian halnya yang terjadi pada para bangsawan pemiliknya. Mereka menghabiskan uang sewa untuk kepentingankepentingan konsumtif dengan dalih memelihara martabat mereka sebagai bangsawan. Dalam hal ini kepentingan para pemilik modal bersambut dengan kebutuhan para bangsawan dan kondisi ini menyuburkan praktik penyewaan tanah (Houben, 2002: 607-608). Karena gaya hidup bangsawan cenderung mewah dan tidak dapat mengatur neraca keuangan, sebagian besar dari mereka terjebak dalam utang kepada para kapitalis China dan juga bank-bank pemerintah risisa. Keadaan ini dengan sendirinya berdampak pada perekonomian kadipaten.

Pada saat P.A.A. Prabu Suryo Dilogo naik tahta keadaan finansial Kadipaten Pakulaman sedang berada pada titik nadir. Dapat dikatakan bahwa raja baru ini mendapatkan warisan tata kelola finansial yang carut marut. Sebab dari kedaan carut marut itu adalah utang kadipaten kepada pemerintah kolonial Belanda dan Internationale Bank (Rotterdamsche Scheepvaart Maatschappij). 
Untuk itu, P.A. V melakukan penghematan bahkan tidak segan-segan menggunakan penghasilan pribadinya untuk membiayai pengeluaranpengeluaran kadipaten. Dampaknya adalah kinerja sehari-hari Kadipaten Pakualaman menjadi sangat bersahaja dan sangat terbatas.

Di pihak lain kerabat Pakualaman masih menjunjung tinggi privilese/hakhak istimewa mereka sebagai anggota keluarga aristokrat. Mereka menikmati penghormatan lahiriah yang diberikan oleh warga kadipaten. Sehubungan dengan itu, atribut yang menandai posisi mereka berupa payung masih ditonjolkan. Kerabat Pakualaman baik tua maupun muda masih selalu dipayungi jika mereka keluar dari tempat tinggal mereka sehingga tampak seperti sebuah perarakan atau karnaval.

Mereka mudah sekali tersinggung jika bertemu dengan orang-orang kebanyakan yang tidak memberikan penghormatan. Tidak jarang terjadi tindakan kekerasan terhadap mereka yang tidak melakukan penghormatan. Untungnya, orang-orang yang mendapatkan perlakuan tidak menyenangkan itu karena didorong oleh rasa hormat dan cinta kepada para bangsawan tidak pernah melakukan perlawanan. Yang sering terjadi adalah para korban itulah yang justru meminta maaf.

Keadaan itu tidak terasa menjadi beban bagi mereka. Di manapun berada mereka selalu menuntut berlakunya hak -hak istimewa. Tidak jarang terjadi perseteruan antara kerabat Pakualaman dan Kesultanan karena kedua belah pihak menuntut berlakunya hak-hak mereka. Bahkan, tidak hanya berupa pertengkaran mulut kadang-kadang di antara mereka juga terjadi perkelahian secara fisik. Peristiwa itu terjadi pada kemeriahan penyambutan gubernur jenderal Hindia Belanda, ulang tahun ratu Belanda atau kunjungan K.G.P.A. Paku Alam-Sultan Hamengku Buwono ke kantor keresidenan. Pertelingkahan itu biasanya dipicu oleh olok-olok dan ejek-mengejek terhadap masing-masing junjungan mereka. Kerabat Pakualaman mengolok-olok Sultan dengan sebutan "dhimas Sultan", sedangkan kerabat Kesultanan menyebut Paku Alam dengan "paman atau kakek Paku Alam." Sebutan itu berasal dari genealogi Sultan dan Paku Alam dalam silsilah dinasti Kesultanan Yogyakarta. Paku Alam V adalah anak dari cucu (buyut) Sultan Hamengku Buwono I.

Pertikaian paling memprihatinkan terjadi ketika salah seorang kerabat keraton dengan sengaja memutus barisan Legiun Pakualaman yang tengah menyambut kedatangan gubernur jenderal. Ia dianiaya oleh komandan legiun, R.M. Koesoemo Pranoto, salah satu kerabat Pakualaman yang dikenal temperamental dan emosional. Korban mengalami luka parah dan nyaris meninggal. Penganiayaan itu menimbulkan konflik terbuka antara kerabat Pakulaman dan Kesultanan. Untuk meredakan ketegangan, pemerintah kolonial terpaksa turun tangan mendamaikan pihak-pihak yang bertikai (Ringkesaning Wawaton, t.t.: 13).

Psikologi kerabat Pakualaman seperti itulah yang harus dihadapi P.A.A. Suryo Dilogo ketika naik tahta. Para bangsawan yang terbiasa hidup berkecukupan dan menikmati banyak privilese di bawah P.A. IV merasa tidak puas dengan kebijakan penghematan itu. Akan tetapi, Suryo Dilogo bergeming. Semua ketidakpuasan itu justru dijadikan cambuk untuk menata perekonomian Kadipaten Pakualaman ke arah yang lebih baik (Ringkesaning Wawaton, t.t.: 12)

Raja terpilih ini menyatakan siap untuk menaati peraturan dan melanjut- 
kan apa yang telah dirintis oleh pendahulunya. Peraturan itu berkaitan dengan polisi, peradilan, dan pelanggran hukum dengan menempatkan seorang asisten residen di wilayahnya. Selain itu, juga dimandatkan untuk pemeliharan jalan, jembatan, dan peningkatan dinas wajib penduduk bumiputra di tanah-tanah sewaan yang disewa oleh orang-orang Eropa. Namun, di antara kewajiban-kewajiban yang harus dipenuhi oleh raja baru itu ialah pemulihan keamanan dan ketertiban untuk kepentingan gubernemen. Sebagaimana dikemukakan di atas, di pundak raja baru ini juga terpikul beban utang kepada pemerintah kolonial dan bank swasta sebesar 100.000 gulden yang harus segera dilunasi. Apabila kewajiban itu dapat ditunaikan dengan baik, gelar Paku Alam dan pangkat kolonel akan segera dianugerahkan (Vereeniging Habi Darmo Wargo, 1931: 24).

Dalam jangka waktu empat tahun raja baru itu dapat menunaikan kewajibannya. Pada 20 Maret 1883 P.A.A. Prabu Suryo Dilogo resmi menyandang gelar Paku Alam V dengan pangkat kolonel. Di samping itu, Paku Alam V juga dianugerahi medali Ridderkruis van den (Orde van) Nederlandschen Leeuw (Salib Kesatria dari Ordo Singa Belanda). Sayangnya, pada 1892 korps bersenjata yang pada 1870 dimekarkan menjadi separo batalion infanteri dan kompeni kavaleri dihapuskan antara lain karena dalam Perang Aceh tidak dapat berperan secara optimal. Tidak dapat dimungkiri demiliterisasi ini mengecewakan P.A. V dan dari beberapa segi mengurangi kewibawaan istana Pakualaman.

Pada dasarnya P.A. V menaruh perhatian besar terhadap eksistensi legiun. Pengeluaran sehari-hari anggota legiun berasal dari kas Kadipaten Pakualaman, walaupun gaji para opsir masih berasal dari Pemerintah Kolonial
Belanda. P.A. V juga mengupayakan hiburan untuk prajurit legiun setelah mereka suntuk berlatih setiap hari. Di pelataran timur Puro Pakualaman acapkali diselenggarakan pertunjukan janggrung, sejenis tayub untuk menghibur mereka. Jika pentas janggrung diadakan para anggota legiun larut dalam kegembiraan. Istri para anggota legiun tidak berkeberatan suaminya menari dengan para penari janggrung. Mereka mendukung suami mereka dengan bertindak sebagai penggembira. Bahkan, mereka juga dengan senang hati turut menyiapkan penampilan para suami mereka (Ringkesaning Wawaton, t.t.: 17).

Sebagaimana diketahui legiun Pakualaman adalah bagian integral dari sistem keamanan Kadipaten Pakualaman yang didirikan pada saat Pangeran Notokusumo naik tahta. Pendirian legiun merupakan bagian dari kontrak politik yang ditandatanganipada 17 Maret 1813 oleh Pangeran Notokusumo (P.A. I) dan John Crawfurd (residen Yogyakarta) mewakili Pemerintah Inggris. Dalam kontrak yang terdiri atas 9 pasal itu antara lain disepakati bahwa Inggris akan melindungi Paku Alam dan keluarganya (pasal 1). Jika Paku Alam tetap menunjukkan iktikad baik dan setia kepada Inggris, yang bersangkutan akan mendapatkan tunjangan bulanan yang berlaku seumur hidup sebesar 750 real dan akan mendapatkan tanah yang berasal dari tanah Sultan Hamengku Buwono II seluas 4.000 cacah. Tanah itu dapat diwariskan kepada anak lelaki tertua Paku Alam (Pasal 2). Kadipaten Pakualaman akan membangun pasukan kavaleri (dragonders) sebanyak 100 prajurit (Pasal 5). Prajurit itu diberi seragam dan dipersenjatai oleh Inggris. Sementara itu, Paku Alam I diminta untuk menyiapkan kuda dan segenap perlengkapannya (Pasal 6). Paku Alam juga diminta untuk menanggung logistik pa- 
ra prajurit dan gaji untuk mereka berdasarkan pangkat mereka. Sersan mendapatkan gaji bulanan 3 real; kopral 2,5 real; prajurit biasa 2 real ( Pasal 7). Para prajurit itu dilatih oleh seorang opsir Inggris dan Paku Alam tidak memiliki hak untuk memecat para prajurit tersebut sebelum mendapatkan izin dari Pemerintah kolonial Inggris (Pasal 8) (Bundels, 1932: 1-4; Poerwokoesoemo, 1985: 150; Poerwokoesoemo: 1987: 4-5).

Pembubaran Legiun Pakualaman sama sekali tidak dibayangkan oleh para anggota legiun. Mereka mendapatkan perintah dari komandan legiun untuk membawa senjata dengan segenap perlengkapannya ke Puro Pakualaman karena akan diganti dengan senjata dan perlengkapan yang baru. Para anggota legiun datang ke puro dengan suka cita. Namun, mereka mendadak berubah menjadi sedih karena mereka baru mengetahui bahwa pada saat itu legiun dibubarkan. Para anggota legiun tersebut ditawari untuk bergabung dengan Tentara Hindia Belanda (Nederland Indische Leger). Akan tetapi, tidak semua prajurit dapat memanfaatkan kesempatan itu. Hanya prajurit muda yang masih sehat dan gagahlah yang dapat memenuhi tawaran itu. Sebagian yang lain, terutama yang sudah tidak muda lagi terpaksa menerima nasib. Semua opsir sepakat tidak memanfaatkan peluang menjadi anggota NIL. Mereka memilih mengundurkan diri dari dinas ketentaraan. Mereka tetap diizinkan mengenakan seragam legiun sesuai dengan pangkatnya masing-masing jika diperlukan. Kepada para opsir itu kemudian diberikan sejumlah kompensasi (Ringkesaning Wawaton, t.t.: 20).

Suasana Puro Pakualaman setelah pembubaran legiun sunyi dan lengang. Biasanya terdengar bunyi tambur yang dipalu dengan bersemangat dan terompet yang melengking dengan gagah. Di samping itu, tidak terlihat lagi prajurit yang berlatih dengan bersemangat. Kampung-kampung di sekitar puro juga terasa sepi (Ringkesaning Wewaton, t.t.: 20).

Gerbang utama sekarang tidak lagi dijaga oleh anggota legiun, tetapi hanya penjaga yang membawa tombak. Itupun tidak berlangsung lama. Para prajurit yang tidak bergabung dengan NIL ditawari menjadi abdi dalem punakawan. Prajurit yang berasal dari unsur kerabat adipati diposisikan sebagai penjaga keamanan dengan mendapatkan belanja seadanya dari kadipaten. Sementara itu, para opsir didudukkan sebagai abdi dalem dengan pangkat wedana (Ringkesaning Wawaton, t.t.: 20).

Bagi sang raja kebijakan itu juga tidak menyenangkan. Namun, dia tidak mau larut dalam kesedihan dan mengungkapkan kekecewaannya secara terbuka. Yang dilakukannya justru sebaliknya yaitu meningkatkan kinerja polisi dan pengadilan. Praktik-praktik penyelundupan dan penyelewengan diatasi dengan kekuatan. Paku Alam V terusmenerus dijiwai oleh semangat untuk memajukan negerinya dibantu oleh putera sulungnya, PA Ario Notokusumo (Vereeniging Habi Darmo Wargo, 1931: 25).

Menurut para saksi mata yang hidup sezaman dengannya, Paku Alam $\mathrm{V}$ dikenal memiliki kepribadian yang menyenangkan dengan tatakrama yang santun serta memiliki banyak sahabat. Seorang yang memiliki pemikiran maju, ramah, dan energik. Di hadapan sejumlah keluarga besarnya, dia dapat menunjukkan kehalusan budinya. Di tengah-tengah rakyatnya dia berpenampilan elegan dan sangat menyadari posisinya sebagai raja (VereenigingHabi Darmo Wargo, 1931: 25). Sementara itu, di kalangan peneliti kebudayaan Jawa berkebangsaan Belanda ia dikenang sebagai tuan rumah yang sangat baik (Stibbe, Wintgens en Uhlenbeck, 1919: 
17)

Berbeda dengan kebanyakan kerabat kerajaan yang lain, Paku Alam V tidak berwatak konservatif. Dia menunjukkan sikap dan pemikiran modern, sangat terpelajar, serta berpikir jauh lebih maju daripada orang-orang sezamannya. Hal itu ditunjukkannya dengan memanfaatkan kesempatan untuk memajukan pendidikan anak-anaknya ke negeri Belanda. Dengan demikian, meskipun Kadipaten Pakualaman merupakan swapraja yang termuda dari empat swapraja penerus Kerajaan Mataram, kadipaten ini merupakan yang pertama memanfaatkan kesempatan itu (Vereeniging Habi Darmo Wargo, 1931: 25; Scherer, 1985: 85; Poeze, 1986: $37-$ 38).

P.A. V sadar bahwa kejayaan masa lalu telah usai. Hak-hak istimewa yang dimiliki oleh para bangsawan sudah saatnya digantikan oleh prestasi. Sehubungan dengan itu, generasi baru Kadipaten Pakualaman harus siap berlomba dengan yang lain untuk menghadapi era baru. P.A. V berkeyakinan bahwa barang siapa tidak mau menyesuaikan diri dengan tuntutan zaman dia akan mengalami kejatuhan. Dipandu oleh keyakinan seperti itu P.A. V dan anak-anaknya menyadari urgensi pendidikan Barat. Meskipun ia tidak berbicara dalam bahasa Belanda, hal itu tidak menghalanginya untuk bergaul dengan orang-orang Eropa di Yogyakarta (Tirtokoesoemo, 1931: 14). Kadangkadang ia tidak keberatan untuk tampil di kalangan orang-orang Eropa di Yogyakarta dengan dibantu oleh seorang penerjemah sebagaimana dilakukan oleh pendahulunya di Kadipaten Pakualaman (lihat Bosma and Raben, 2008: 116).

Dengan dukungan Paku Alam Studie Fond (Dana Studi Paku Alam) dan bantuan serta insentif dari Vrijmetselarij Paku Alam V mengizinkan semua anaknya, termasuk anak-anak perempuannya menempuh pendidikan Barat, bahkan sampai ke negeri Belanda (Niel, 2009: 79). Misalnya, Notodirojo merupakan pangeran Jawa pertama yang menempuh pendidikan HBS. Dia menjadi pendukung utama gagasangagasan dr. Wahidin Sudirohusodo dan menjadi ketua Budi Utomo pada periode kepengurusan kedua pada $1911-$ 1914. Di Kadipaten Pakualaman Notodirojo menjadi anggota Dewan Pengelola (Raad van Beheer) dan sebagai pangeranbupati yang selalu mencurahkan tenaganya untuk kepentingan bangsa dan negaranya.

Anak keempat, Pangeran Kusumo Yudo yang sejak usia kanak-kanak menempuh pendidikan di negeri Belanda (ELS dan HBS di Nijmegen dan mahasiswa Fakultas Kedokteran di Amsterdam) menjadi anggota Dewan Hindia Belanda (Raad van Nederlandsch-Indië). Pangeran yang intelek dan rendah hati ini memulai kariernya sebagai calon kontrolir (adspirant controleur) pada Pemerintahan dalam Negeri (Binnenlandsch Bestuur), kemudian menjadi kontrolir, administrator, dan dipromosikan sebagai bupati Ponorogo selama 12 tahun. Dia juga menjadi anggota Dewan Rakyat (Volksraad) sejak organisasi ini berdiri pada 1918 sampai dengan 1929. Pada periode persidangan yang kedua dan ketiga, dia menjadi ketua pengganti, sedangkan pada periode terakhir dia menjadi wakil ketua para utusan. Jabatan ini merupakan prestasi yang paling tinggi yang dapat dicapai oleh seorang bumiputra yang diperolehnya karena pendidikan yang ditempuhnya di Negeri Belanda dan pengabdiannya yang terus-menerus selama dua puluh enam tahun kepada pemerintah (Vereeniging Habi Darmo Wargo, 1931: 27; Nagazumi， 1989: 35-36; Djojohadikusumo, t.t.: 59-62).

Anak ke-9 Paku Alam V, R.A. Su- 
miyati yang kemudian menjadi R.A.A. Ario Purbahadikusumo, istri bupati Kutoarjo (wilayah Kabupaten Purworejo) dikenal di kalangan bumiputra dan Eropa karena keahliannya dalam bidang sastra dan musik Jawa. Sementara itu, anak perempuannya yang lain, anak ke10, R.A. Miryam berkeinginan memperoleh akta middelbaar onderwijs (MO) di negeri Belanda. Sayangnya, pendidikan persiapan yang diperolehnya di Yogyakarta tidak memenuhi persyaratan yang ditetapkan. Sebagai gantinya, ia mengikuti kursus bahasa Inggris baik di Belanda maupun Inggris. Ia pernah diterima oleh Ratu Wilhelmina dan Ratu Emma ketika tinggal di Belanda serta Raja George V dan permaisuri ketika belajar bahasa Inggirs di Inggris. Di kalangan masyarakat Batavia -Koninkelijk Bataviaasch Genootschaap van Kunsten en Wetenscappen (Perhimpunan Masyarakat Batavia untuk Kesenian dan Ilmu Pengetahuan) - putri keraton ini juga merupakan sosok yang mencolok karena pengetahuannya yang luas mengenai bahasa. Dalam sebuah suratnya yang dikirimkan dari London 30 Juni 1923 kepada redaksi majalah Oedaya, Mirjam menginginkan kaum perempuan, terutama perempuan Indonesia mempunyai kesempatan yang sama dengan laki-laki terutama dalam mengakses media massa (Oedaya, No. 10, Januari 1924; Vereeniging Habi Darmo Wargo, 1931: 27; Poeze, 2008: 166). Mirjam meninggal dunia dalam kesendiriannya di Den Haag pada 1972 dalam usia 72 tahun.

Putra yang ke-11, R.M. Suryoputro dikirim untuk belajar teknik sipil di Delft. Akan tetapi, Perang Dunia I mengubah secara total cita-citanya (Oedaya, V, No. 9 : 141). Dalam perkembangannya Suryoputro lebih banyak menekuni bidang kesenian, terutama musik dan tari. Ia berpandangan bahwa jiwa bangsa dapat dikenal dengan baik melalui karya seni musik nasionalnya.
Melalui ekspresi estetis itu, jiwa Barat dan Timur akan lebih mudah dikomunikasikan. Suryoputro banyak mempublikasikan gagasan-gagasanya tentang teori musik, terutama mengenalkan musik Jawa dengan notasi musik Barat di media massa Belanda, Nederlandsch-Indië Oud en Nieuw (NION). Artikelartikelnya dalam lima tahun pertama penerbitan NION menunjukkan bahwa ia melakukan kajian yang mendalam dan menguasai dengan baik musik Timur dan Barat (Poeze, 2008: 105).

Bersama dengan kerabat Pakualaman yang lain, R.M. Suwardi Suryaningrat, R.M. Noto Soeroto, dan putra patih Kesultanan Yogyakarta, R.M. Yojana, Suryoputro mendirikan LangenDriyo, perkumpulan musik dan tari Jawa. Perkumpulan itu memperoleh dukungan dan simpati dari para pendukung paham etis dalam majalah Nederlandsch -Indië Oud en Nieuw dan organisasi Oost en West serta masyarakat seniman Belanda yang mendapatkan inspirasi dari kebudayaan dan kesenian Jawa. Pada 1916 misalnya, di Schouwburg (gedung pertunjukkan) di Den Haag, Oost en West bekerja sama d e n g a n L a n g e n - D r i y o menyelenggarakan pertunjukkan amal untuk korban bencana banjir di HindiaBelanda. Kostum dan dekorasi untuk acara itu ditata oleh seorang seniman Belanda, sedangkan para penarinya adalah Soewardi, Soerjopoetro, Noto Soeroto, dan Jodjana. Ratu Wilhelmina, tamu kehormatan dalam cara itu merasa puas terhadap terhadap pertunjukkan tari dan musik yang digelar oleh salah seorang tawanan politik yang menuntut kemerdekaan itu (lihat juga Poeze, 1986: 109).

Dalam surat kabar Wendingen (Perubahan) pada 1919, Suwardi menjelaskan arti politis pertunjukkan tari Jawa bagi masyarakat Belanda. Pertunjukkan Langen-Driyo ingin 
membuka mata masyarakat Belanda bahwa bangsa Hindia-Belanda adalah sebuah bangsa yang memiliki hak untuk menentukan nasibnya sendiri. Dalam edisi yang sama Suryoputro juga mengungkapkan bahwa pertunjukkan itu dimaksudkan untuk menunjukkan kepada masyarakat Eropa Barat keindahan kebudayaan Jawa. Di samping itu, dia berharap bahwa pertunjukan tersebut dapat menarik perhatian masyarakat luas terhadap suatu masyarakat (Hindia Belanda) yang sudah dalam waktu yang lama mengalami depresi moral (Waaldijk en Susan Legêne, 2009: 187-211)

Putranya yang lain, putra ke-12, R.M. Notowiroyo dikirim untuk belajar di sekolah dagang di Amsterdam. Namun, penyakit TBC menghancurkan pertahanan tubuhnya. Meskipun pengobatan secara medis telah dilakukan bahkan yang bersangkutan diberi kesempatan tetirah di sebuah sanatorium di sebuah dataran tinggi di Swiss, nyawa Notowiroyo tidak dapat $\mathrm{d}$ i se la m a tkan. Notowiroyo menghembuskan nafas terakhir di tempat itu (Poeze, 2008: 152).

Kematian Notowiroyo sangat mengenaskan. Selama empat hari jenazahnya tidak terurus karena tidak ada satu pihakpun yang bersedia bertanggung jawab.Diduga wali Notowiroyo tidak berbuat apapun karena tidak mendapatkan kiriman biaya pengurusan jenazah dari keluarga Pakualaman. Kematian Notowiroyo menjadi berita besar di kalangan perhimpunan mahasiswa Indonesia di Belanda, khususnya di Leiden. Akhirnya, mereka melaporkan kejadian tragis itu kepada Abendanon yang kemudian menuju Swiss untuk mengurus administrasi kematian Notowiroyo. Dengan bantuaan Abendanon, jenazah Notowiroyo dikuburkan di Swiss (Rivai, $2000: 7$ ). Kematian Notowiroyo menunjukkan bahwa krisis finansial di Kadipaten Pakualaman belum sepenuhnya dapat diatasi.

Dalam Voordrachten en Mededeelingen van Indische Vereeniging (Ceramah dan Informasi Perhimpunan Hindia) Abendanon (via Poeze, 2000: 152) mengenang Notowiroyo sebagai seorang pemuda yang memiliki semangat tinggi untuk menuntut ilmu bagi kemajuan bangsanya. Pilihannya pada bidang ekonomi menunjukkan ia sadar bahwa pengetahuan tentang perekonomian dan perdagangan dunia merupakan pilar penting bagi kemajuan. Meskipun cita-citanya tidak tercapai ia telah member teladan tentang keberanian dan keteguhan untuk menuntut ilmu yang berguna bagi negaranya.

Kedekatan P.A. V dengan Tarikat Mason Bebas terjalin sejak P.A. V masih menyandang nama P.A. Suryo Dilogo. Pada 1871, ia dikukuhkan sebagai anggota kehormatan tarikat itu di Loji (lodge) Mataram, Yogyakarta. Bergabungnya P.A. V dengan Tarikat Mason Bebas merupakan prestasi dan sekaligus prestise bagi tarikat tersebut. Ia merupakan anggota keluarga kerajaan Jawa pertama yang menyatakan diri bergabung dengan tarikat tersebut. Keanggotaan PA diharapkan menjadi magnet bagi keluarga bangsawan Jawa yang lain untuk menjadi anggota. Anak-anak P.A. $\mathrm{V}$ kemudian juga tercatat sebagai anggota Tarikat Mason Bebas, seperti P.A. Notokusumo (P.A. VI), P.A. Notodirojo, P.A. Kusumoyudo, dan bahkan cucunya P.A. VII (Stevens, 2004: 29-30).

Alasan tentang kesediaan para penguasa Kadipaten Pakualaman bergabung dengan Tarikat Mason Bebas tidak pernah terungkap dengan jelas. Akan tetapi, kemungkinan besar mereka tertarik kepada anggaran dasar tarikat 
yang menempatkan kesetaraan dan pluralisme sebagai tujuan yang penting. Dalam pasal 2 ayat 4 disebutkan bahwa tarikat mengakui: (1) nilai kepribadian manusia; (2) hak setiap orang untuk mencari kebenaran secara mandiri; (3) persamaan dalam wujud semua manusia (Stevens, 2004: 6). Kemungkinan mereka juga tertarik pada upacaran dan ritual serta humanisme yang ditonjolkan dalam pertemuanpertemuan tarikat sebagaimana yang dirasakan oleh R.M.A.A. Poerba Hadiningrat, mantan bupati Semarang dan Salatiga (Hadiningrat, 1927: $134-$ 143; Veur, 2012: 83-84).

Dalam pemerintahan sehari-hari Paku Alam V di ibukota kerajaan dibantu oleh seorang patih yang membawahi seorang kliwon patih dan mantri jurutulis serta beberapa orang jurutulis. Untuk pemeliharaan keamanan patih dibantu oleh polisi kota meliputi polisi panekar berjumlah empat di Gunungketur, Jagalan, Purwanggan, dan kepatihan. Para polisi ini dibantu oleh kebayan kampong terdiri atas tokoh-tokoh yang disegani di kalangan masyarakat setempat. Sementara itu, di luar ibukota, dalam hal ini di wilayah Adikarto (sekarang masuk wilayah Kabupaten Kulonprogo) pemerintahan sehari-hari dijalankan oleh seorang rio bupati yang dibantu oleh dua orang panewu pangreh praja (di Pandowan dan Sogan) dan empat orang mantri polisi yang kedudukannya setara asisten wedana di Bendungan, Wates, Sindutan, dan Karangwuni (Ringkesaning Wawaton, t.t.: 8).

Untuk persoalan hukum, Pengadilan Darah Dalem (Raad Kasentanan) dan pengadilan umum bertugas menangani dan memutus perkara. Kewenangan itu dijalankan oleh Jaksa Agung Hukum Pakualaman (Jaksa Ageng Pradata Pakualaman) dibantu oleh dua orang wakil jaksa, beberapa orang juru tulis dan enam orang jagalatri atau jagawesti yang memiliki kedudukan seperti polisi. Para jagalatri atau jagawesti ini memiliki kewenangan memenjarakan orang-orang yang telah diputus bersalah. Pengadilan Pakualaman juga memiliki kewenangan menjatuhkan hukuman mati. Dengan demikian, dari segi kewenangan, pengadilan ini tidak berbeda dengan pengadilan Landraad pada waktu itu (Ringkesaning Wawaton, t.t.: 8).

\section{TATA PAMONG PADA MASA P.A. V}

Paku Alam V merupakan penguasa Kadipaten Pakualaman yang pertama melakukan pembagian kekuasaan secara terstruktur. Sebagai pemimpin karismatis--meminjam istilah Max Weber-yang sudah sejak lahir memiliki kualitas individual yang mendudukkannya berbeda dengan orang kebanyakan dan dianggap dikaruniai kekuatan supranatural serta adimanusiawi untuk memimpin sebuah dinasti ( Pugh and Hickson, 2007: 4; Winkler, 2010: 32), kesediaan Paku Alam V untuk berbagi kekuasaan merupakan tindakan yang terpuji. Baginya, kekuasaan bukan sesuatu yang tidak terbagi dan harus terus-menerus dipertahankan kekeramatan serta keutuhannya. Kekuasaan dapat dibagi dan didelegasikan kepada orang-orang yang dipercayainya. Kemungkinan besar sifat ini juga terbentuk berkat pergaulannya yang luas dengan para pengikut vrijmetselarij, semacam teologi pembebasan yang sangat menekankan kesetaraan dan menolak pembedaan manusia berdasarkan ras, bangsa, dan agama dengan tujuan berpartisipasi secara aktif dalam proses pembangunan negara dan bangsa secara harmonis (Surjomihardjo, 2008: 47-49). Paku Alam V tahu bahwa kualitas kepemimpinan antara lain ditentukan oleh penegakan hukum, pendelegasian wewenang, dan pembagian kekuasaan. 


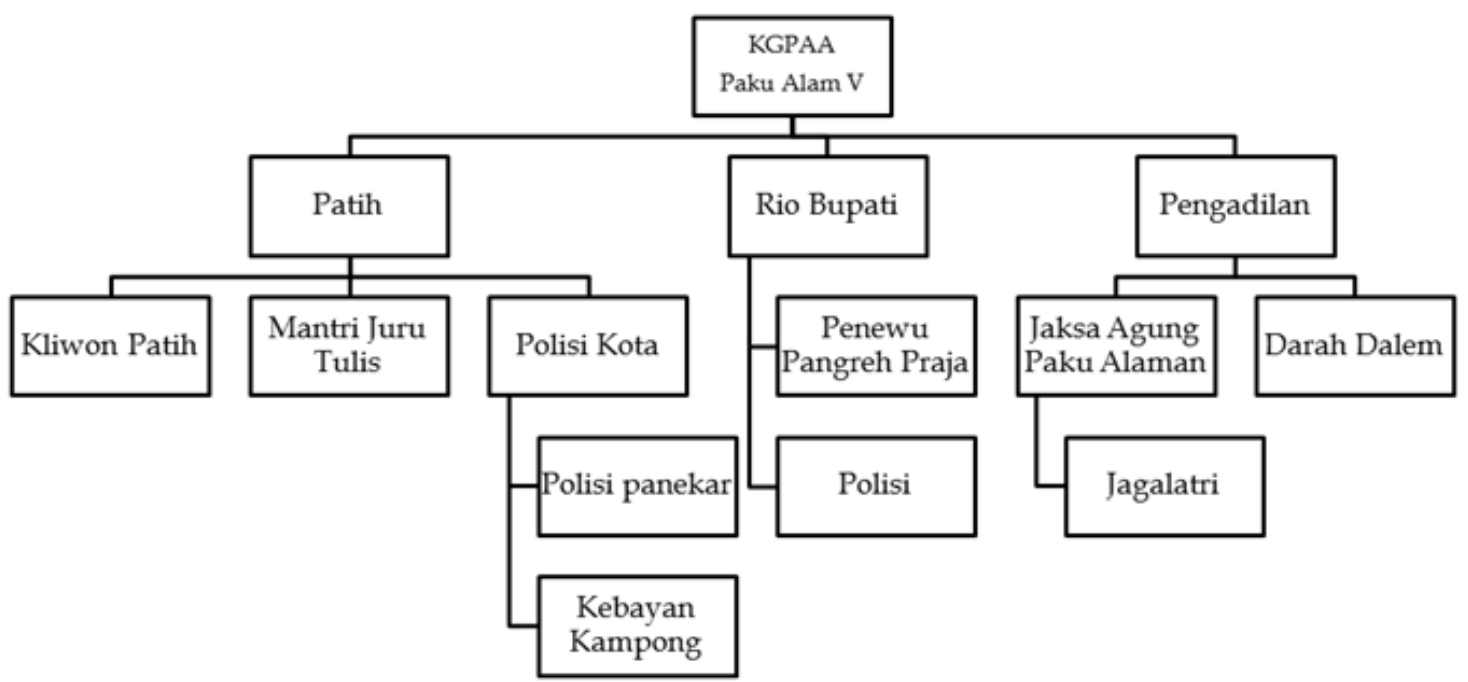

Gambar 1. Pembagian Tata Pamong Paku Alam V (Sumber: Sudibyo, 2012: 20)

Paku Alam V memadukan gaya kepemimpinan tradisional dan modern. Hal ini terjadi karena Paku Alam V terbuka terhadap perubahan dan mampu membaca tanda-tanda zaman yang pada masa itu, yaitu pada peralihan abad ke-19 ke abad ke-20 sudah menunjukkan fajar perubahan.

Meskipun dari sisi birokrasi Kadipaten Pakualaman mengalami kemajuan, dari sisi lain, yaitu segi finansial, kadipaten belum memiliki pengaturan yang baik. Sumber-sumber pendapatan yang seharusnya dapat diperoleh dari pajak belum dioptimalkan, misalnya pajak penghasilan (inkomsten belasting), pajak upah (loon belasting), pajak bumi dan bangunan (verponding belasting), dan pajak tontonan (vermakkelijkheid belasting). Yang sudah diberlakukan adalah pajak tanah milik kadipaten dan pajak pekerjaan yang tidak dapat diandalkan sebagai penghasilan kadipaten ((Ringkesaning Wawaton, t.t.: 9).

Karena kadipaten belum memanfaatkan secara maksimal sumbersumber keuangan, tidak ada badan khusus yang bertugas mengurusi pemasukan finansial. Sehubungan dengan itu, semua pemasukan langsung disam- paikan kepada penguasa puro. Dengan demikian, tanggung jawab atas keuangan sepenuhnya juga berada di tangan penguasa puro.

Reformasi birokrasi dan keuangan yang dilakukan oleh Kadipaten Pakualaman terutama di wilayah Adikarto tidak dapat dilepaskan dari jasa K.P.H. Noto Dirojo. Putra ke-5 sang adipati ini ditugasi ayahandanya untuk mengurusi soal-soal keuangan. Bagi Noto Dirojo meskipun merupakan suatu kehormatan tugas itu merupakan tugas yang tidak ringan karena menuntut tanggung jawab yang sangat berat. Pada waktu itu, keadaan kas Kadipaten Pakualaman dalam keadaan yang sangat tidak menggembirakan karena defisit keuangan warisan pendahulu ayahnya (Dewantara, 1994: 351). Situasi itu, melalui surat, disampaikan oleh K.P.H. Noto Dirojo kepada anak-anaknya yang sedang menempuh pendidikan di negeri Belanda.

Oh, anak-anakku. Kalian pasti tak bisa membayangkan seperti apa keadaannya ketika aku mulai bertugas di kadipaten. Bahkan sebagian besar kebutuhan pokok kami tak punya. Bayangkan, ketika eyang ka- 
lian ingin mengadakan resepsi atau pesta...kami selalu harus meminjam kursi, lampu, gelas dan sebaginya, dari sana-sini agar dapat menjamu tamu. (Djajadiningrat-Nieuwenhuis, 2000: 31).

Dalam waktu singkat K.P.H. Noto Dirojo mempelajari sebab-sebab krisis keuangan yang melanda Kadipaten Pakualaman yang ternyata diakibatkan oleh ketidakseimbangan neraca keuangan karena jumlah pengeluaran jauh melebihi pemasukan. Kondisi ini menyebabkan kadipaten terjerat utangutang dalam jumlah besar (f.100.000) dengan bunga tinggi (15\%--30\%). Untuk itu, sebagai administrator lulusan HBS Jakarta dan Semarang, secara berkala K.P.H. Noto Dirojo merasa perlu untuk mendatangi dan memeriksa sendiri pekerjaan-pekerjaan bawahannya untuk mengetahui apakah uang yang dikeluarkan benar-benar digunakan secara bertanggung jawab. Kebijakan pangeran muda yang sangat tegas dan tanpa kompromi ini mendatangkan ketidaksukaan di kalangan pegawai istana dan bawahannya. Akan tetapi, dia bergeming sampai berhasil mencapai tujuannya, yaitu keseimbangan neraca keuangan kadipaten. Di samping itu, juga dilakukan penghematan besar-besaran sehingga pada 1889 semua utang kecuali utang kepada Pemerintah Kolonial Hindia Belanda telah terbayar (Dewantara, 1994: 352; DjajadiningratNieuwenhuis, 2000: 31).

Melihat keberhasilan K.P.H. Noto Dirojo menata keuangan kadipaten, Paku Alam V kembali menugasinya untuk menyelesaikan persoalan-persoalan keagrariaan di daerah Adikarto yang pada waktu itu belum tertata dengan baik. Dia segera menerbitkan peraturan sewa-menyewa dan perpajakan. Oleh pangeran ini diputuskan bahwa penyewaan tanah tidak dilakukan melalui perantaraan kepala-kepala distrik, tetapi langsung kepada warga yang membutuhkannya.Karena itu, perjanjianperjanjian yang sudah dibuat dan merugikan rakyat banyak, sesudah habis masa berlakunya tidak dilanjutkan lagi.

Tanah-tanah yang diperoleh kembali oleh kadipaten dengan kebijakan itu kemudian diberikan kepada rakyat yang memerlukannya dengan sistem bagi hasil. Hal ini mendatangkan kesulitan bagi sang pangeran karena dia harus menyelaraskan kepentingan pabrik gula yang telah memiliki konsesi atas tanah-tanah itu dan kepentingan rakyat. Akan tetapi, karena tugas itu dilakukan dengan niat luhur untuk memperbaiki keadaan, tugas tersebut dapat dilaksanakan dengan baik.

\section{HARI-HARI TERAKHIR PAKU ALAM V}

Satu dasawarsa sebelum wafat, P.A. V mulai memperhatikan kepentingan pribadinya yang terabaikan. Untuk menghibur hati, ia membangun tempat pesiar di muara Sungai Bogowonto dengan cara membuat sudetan berupa sungai kecil ke arah Barat. Tempat itu dinamainya Pasir Mendit. Ia sangat menyukai tempat pesiar di tepi laut selatan yang kontemplatif itu. Dari situ terdengar dengan jelas kesiur angin dan deburan ombak yang menyapu pantai. Lagipula, tempat yang terpencil dari wilayah sekitarnya itu hening dan senyap. Paku Alam V sangat betah berada di tempat itu. Jika sudah berada di tempat itu, berbulan-bulan ia tidak pulang ke istana Pakualaman. Ia lebih suka menetap di Pesanggrahan Glagah. Hal lain yang diakukannya adalah menyiapkan lahan pemakaman di puncak Bukit Girigondo dengan dibantu kerabat yang menyertainya (Wawaton, t.t.: 28).

Pada saat-saat pulang ke Puro 
Pakualaman, ia memerintahkan para seniman istana untuk menggelar latihan wayang orang dengan lakon Gondowerdoyo. Gondowerdoyo adalah lakon wayang orang ciptaan Sultan Hamengku Buwono I. Lakon ini berkisah tentang "pencarian ayah" yang dilakukan dua anak Arjuna, Gondowardoyo dan Gondokusumo yang lahir dari dua ibu yang berbeda (Soedarsono, 1984: 347). Tampaknya, lakon ini merupakan representasi masa lalu Paku Alam V ketika dipisahkan dari kehidupan istana. Oleh karena itu, meskipun latihan dilakukan dengan sangat baik, lakon tersebut tidak pernah dipertontonkan untuk umum karena keinginannya adalah hanya untuk menghibur hati. Demikian pula halnya dengan latihan Surasarani yang berasal dari Babad Segaluh, repertoir sendratari itu juga tidak untuk dipergelarkan kepada masyarakat umum.

Paku Alam V juga memperluas kompleks Puro Pakualaman ke arah Utara. Banyak pekarangan yang digunakan untuk perluasan itu. Sebagai gantinya, para pemilik lahan diberi lahan pengganti milik Pakualaman atau kompensasi berupa uang. Di sela-sela perluasan kompleks puro, dilakukan latihan berbagai jenis tarian. Namun, yang mendapatkan perhatian khusus adalah penciptaan sendratari Banjaransari dengan peraga 40 penari yang mayoritas berjenis kelamin perempuan dan masih kanak-kanak. Mereka adalah anak-anak abdi dalem yang dididik secara khusus di lingkungan Puro Pakualaman di bawah pengawasan para selir Paku Alam V. Sendratari Banjaransari di samping dinikmati oleh kalangan dalam puro juga dipertontonkan untuk umum. Setiap menyaksikan pergelaran Banjaransari, Paku Alam V merasa sangat terhibur. Sendratari itu juga sangat disukai masyarakat (Ringkesaning
Wawaton, t.t.: 28; Kusmayati, 2012: 88).

Setelah perluasan kompleks puro selesai, Paku Alam V kembali membangun tempat pesiar di Bugel dengan diawasinya sendiri. Untuk sementara, pergelaran sendratari Banjaransari dihentikan. Namun, jika ia pulang ke Puro Pakualaman pergelaran itu kembali diadakan. Peristiwa itu terjadi beberapa kali sampai akhirnya pada suatu ketika Paku Alam V pulang dari tempat peristirahatannya dalam keadaan sakit. Paku Alam menderita sakit karena abses di rongga telinganya. Berbagai macam pengobatan untuk penyembuhan baik berupa pengobatan tradisonal maupun pengobatan secara medis dilakukan, tetapi semakin hari sakitnya tidak kunjung sembuh malahan semakin parah. Akhirnya pada hari Sabtu tanggal 6 November 1900, Paku Alam V wafat. Jenazahnya kemudian dimakamkan di makam Girigondo dengan menggunakan kereta api khusus. Pada waktu itu makam Girigondo masih berupa gundukan bukit belum tampak sebagai kompleks pemakaman raja-raja (Ringkesaning Wawaton, t.t.: 29; De Nieuwe Vorstenlanden, 1 maart 1901).

\section{SIMPULAN}

Meskipun secara resmi tidak pernah diketahui melakukan upayaupaya untuk meningkatkan kecerdasan intelektual, Paku Alam V adalah salah satu dari sedikit aristokrat Jawa yang memilik kemampuan membaca tandatanda zaman. Ia berhasil membangun kebanggaan baru kaum bangsawan Jawa, tidak dari darah biru yang mengalir dalam urat nadinya, tetapi dari prestasi yang dicapainya. Pintu masuk untuk meraih prestasi itu adalah pendidikan Barat. Meskipun tidak terdidik di arena itu, dengan sekuat 
tenaga ia mendorong anggota keluarganya untuk menempuh pendidikan Barat karena ia memiliki kesadaran bahwa pendidikan Barat dapat mengubah tatanan batin anggota keluarga besarnya untuk menjadi lebih cendekia.

Dengan pendidikan modern setidak-tidaknya dua hal akan dapat dicapai. Pertama, untuk jangka waktu tertentu konflik kepentingan di antara anak keturunannya karena menginginkan tahta akan dapat diredakan. Kedua, melalui pendidikan terutama melalui keahlian yang diperoleh akan dapat ditingkatkan taraf hidup keluarga besarnya mengingat Kadipaten Pakualaman adalah kadipaten termiskin jika dibandingkan dengan tiga swapraja yang sudah ada sebelumnya. Oleh karena itu, hanya melalui pendidikan Barat yang membukan jejaring antara kerabat Pakualaman dan berbagai profesi, kerabat Pakualaman akan dapat berkiprah dalam berbagai bidang pengabdian yang pada gilirannya akan meningkatkan kesejahteraan anggota keluarga besarnya. Semua itu berpotensi mendukung keberadaan Kadipaten Pakualaman di tengah-tengah masyarakat.

Kesediaanny menerima kehadiran zaman baru yang dengan sendirinya mengurangi hak-hak istimewanya sebagai seorang bangsawan menunjukkan dedikasinya kepada kemajuan anggota keluarga besarnya. Dengan demikian, Paku Alam $\mathrm{V}$ berhasil tampil sebagai sosok aristomodernis, dua karakter yang pada waktu itu sulit disandingkan. Paku Alam V sekaligus juga merupakan sosok yang paradoks. Pada umumnya bangsawan menunjung tinggi aristokrasi dan privilesenya. Untuk itu, ia tidak tertarik dengan ide-ide modernisasi tentang kesetaraan dan pemerataan karena hanya akan mengurangi hak-hak istimewanya. Namun, P.A. V yang sudah mempelajari humanisme dan kesetaraan antarsesama ras manusia dalam lingkaran Tarikat Mason Bebas (vrijmetselarij) dengan segala risiko menerima tantangan modernisasi dan melepaskan sebagian dari hak-hak istimewanya. AristoModernis ini wafat dengan tidak meninggalkan warisan kekayaan kepada anak keturunannya. Sebagai gantinya, ia meninggalkan anak keturunan yang siap mengabdi pada berbagai kepentingan kemanusiaan, seperti birokrat, teknokrat, pendidik, dan budayawan.

\section{UCAPAN TERIMA KASIH}

Tulisan ini merupakan bagian dari penelitian berjudul Westernisasi dan $\mathrm{Pa}$ radoks Kebudayaan yang dilakukan bersama dengan Sri Margana, Sri Ratna Saktimulya, Mutiah Amini, dan Baha'udin yang dibiayai oleh Unit Penelitian Fakultas Ilmu Budaya UGM pada Tahun Anggaran 2013.

\section{DAFTAR PUSTAKA}

Bosma, Ulbe and Remco Raben. 2008. Being "Dutch" In the Indies: A History of Creolisation and Empire, 1500-1920. Singapore: NUS Press.

Cakrasumarta dan Panji Himadigdaya. 1987. Silsilah Keluarga Paku Alam Sejak Paku Alam I sampai Paku Alam VIII. Yogyakarta: Yayasan Notokusumo.

Conger, J.A. and R.N. Kanungo.(Eds.) 1998.Charismatic Leadership in Organizations.Thousand Oaks: Sage Publications.

Bundels met Gegevens BG IV No. 8 Toenggoelwoeloeng-Ommegang, Ont. Van R. Soedjana Titakoesoema (sic), Yogyakarta 1932. Mikrofilm No. 
692/73 koleksi KITLV.

De Locomotief. 27 September 1878.

De Nieuwe Vorstenlanden. "Prins Pakoe Alam." Vrijdag, 1 maart XXX-E Jaargang 1901, No. 5.

Dewantara, Ki Hadjar. 1994. "PA Notodirodjo dan Sumbangannya dalam Kebangkitan Bangsa Jawa". Tim Penerbitan Buku Khusus Ajaran Ki Hadjar Dewantara. 1994. Karya Ki Hadjar Dewantara: Kebudayaan. Yogyakarta: Majelis Luhur Persatuan Taman Siswa.

Djajadiningrat-Nieuwenhuis, Madelon. 2000. "Noto Soeroto: Aristo-Demokrat Tanpa Pendukung". Jurnal Kebudayaan Kalam, No. 16, 2000.

Djojohadikusumo, Margono. t.t. KenangKenangan dari Tiga Zaman: Satu Kisah Kekeluargaan Tertulis. Jakarta: Indira.

Furnivall, J.S. 2009. Hindia Belanda: Studi tentang Ekonomi Majemuk. Diterjemahkan oleh Samsudin Berlian. Jakarta: Freedom Institute.

Hadiningrat, R.M.A.A. Poerba. 1927. Wat Ik als Javaan voor Geest en Gemoed in de Vrijmetselarij Heb Gevonden. Den Haag: W.P. Van Stockum \& Zoon.

Kusmayati, A.M. Hermin. 2012. "Kesenian: Seni Tari". Saktimulya, S.R., Sudibyo, dan B. Sumardiyanto. (Eds.). Warnasari Sistem Budaya Kadipaten Pakualaman. Yogyakarta: Perpustakaan Pakualaman-Eka Tjipta FoundationTrah Pakualaman Hudyana.

Lombard, Denys. 1996. Nusa Jawa Silang Budaya: Warisan Kerajaan-kerajaan Konsentris. Jilid 3. Jakarta: Gramedia Pustaka Utama.

Nagazumi, Akira. 1989. Bangkitnya Nasionalisme Indonesia: Budi Utomo 1908 1918. Jakarta: Grafiti.

Niel, Robert van. 2009. Munculnya Elite Modern Indonesia. Diterjemahkan oleh Zahara Deliar Noer. Jakarta: Pustaka Jaya.

Oedaya, No. 10, Januari 1924. " Het Oordel van een Javaansche Prinses over Ons Blad."

Oedaya, V, No. 9, September 1928. "In Memoriam Rd. Ms.Ario Soerjopoetro."

Poerwokoesoemo, Soedarisman. 1985. Kadi- paten Pakualaman. Yogyakarta: Gadjah Mada University Press.

------. 1987. Peranan Beberapa Tokoh Wanita di Puro Pakualaman. Yogyakarta: Yayasan Ilmu Pengetahuan dan Kebudayaan Panunggalan (Lembaga Javanologi).

Poeze, Harrry A., Cees van Dijk en Inge van der Meulen. 1986. In het Land van de Overheerser I: Indonesiërs in Nederland 1600 - 1950. Dordrecht-Cinnaminson: Foris Publications.

Pratt, Mary Louise. 1992. Imperial Eyes: Travel Writing and Transculturation. London: Routledge.

Pugh, Derek S. and David J. Hickson. 2007. Great Writers on Organizations: The Third Omnibus Edition. HampshireBurlington: Ashagate.

Rivai, Abdul. 2000. Student Indonesia di Eropa. Jakarta: KPG-IKAPI-The Ford Foundation.

Said, Edward. 2003 . Orientalism. (25 th Anniversary Edition with a New Preface by the Author). New York: Vintage Books.

Sudibyo. 2012. "Tata Pamong". Saktimulya, S.R., Sudibyo, dan B. Sumardiyanto. (Eds.). Warnasari Sistem Budaya Kadipaten Pakualaman. Yogyakarta: Perpustakaan Pakualaman-Eka Tjipta Foundation-Trah Pakualaman Hudyana.

Scherer, Savitri Prastiti. 1985. Keselarasan dan Kejanggalan: Pemikiran_pemikiran $\mathrm{Na}$ sionalis Jawa Awal Abad XX. Diterjemahkan oleh Jiman S. Rumbo. Jakarta: SinarHarapan.

Soedarsono. 1984. Wayang Wong: The State Ritual Dance Drama in The Court of Yogyakarta. Yogyakarta: Gadjah Mada University Press.

Sosrosoedarmo, R.M.P. 1931. "Biographie van Zijne Hoogheid PAA. Pakoe Alam VII" in Gedenkschrift Uitegeven ter Gelegenheid van het 25-Jarig Bestuurs -Jubileum van Zijne Hoogheid PAA. Paku Alam VII Hoofd van het Paku Alamsche Huis 1906-1931. Djokja: Van Buning.

Stevens, Th. 2004. Tarikat Mason Bebas dan Masyarakat Hindia Belanda dan 
Indonesia 1706-1962. Diterjemahkan oleh Perides Katoppo. Jakarta: Sinar Harapan.

Stibbe, D.G., W.C.B. Wintgens en E.M. Uhlenbeck (Reds.). 1919. "Pakoe Alam V." Encyclopaedie van Nederlandsch-Indië, Derde Deel, NSoema. 'S-Gravenhage-Leiden: Martinus Nijhoff-E.J. Brill (Tweede Druk).

Surjomihardjo, Abdurrachman. 2008. Kota Yogyakarta Tempo Doeloe: Sejarah Sosial 1880-1930.

Tanpa Pengarang. Tt. Ringkesaning Wewaton (Patokan-Punten). Koleksi Perpustakaan Pura Pakualaman.

Tirtokoesoemo, Sudjono R. 1931. "Jeugdherinneringen". in Gedenkschrift Uitegeven ter Gelegenheid van het 25-Jarig Bestuurs-Jubileum van Zijne Hoogheid PAA. Paku Alam VII Hoofd van het Paku Alamsche Huis 19061931. Djokja: Van Buning.

Vereeniging Habi Darmo Wargo. 1931. Vereeniging Habi Darmo Wargo Uitegeven ter Gelegenheid van het 25-Jarig Bestuurs -Jubileum van Zijne Hoogheid PAA. Pakoe Alam VII Hoofd van het Pakoe Alamsche Huis 1906-1931. Batavia: Albrecht \& Co.

Veur, Paul W. van der. 2012. Freemasonry di Indonesia: Jaringan Zionis Tertua yang Mengendalikan Nusantara. Diterjemahkan oleh Jagat Purbawati. Jakarta: Ufuk Press.

Waaldijk, Berteke en Susan Lagêne. 2009. "Ethische Politiek in Nederland: Culturele Burgerschap tussen Overheersing, Opvoeding en Afscheid." Bloembergen, Marieke en Remco Raben.(eds). 2009. Het Koloniale Beschavingsoffensief: Wegen naar het Nieuwe Indië 1890-1950. Leiden KITLV: Uitgeverij.

Winkler, Ingo. 2010. Contemporary Leadership Theories: Enhancing the Understanding of the Complexity, Subejectivity and Dynamic of Leadership. Berlin-Heidelberg: Springer-Verlag. 